\title{
Gastón Chaves, El Derecho Penal desde la Constitución, UCU, Montevideo, 2015, 764 pp.
}

Con esta obra de gran envergadura, fruto de años de investigación, el Dr. Gastón Chaves presenta un planteo actual y profundo de temas medulares del Derecho Penal. Como tal, este trabajo no tiene antecedentes en la doctrina uruguaya y resulta de consulta insoslayable para los estudiosos y especialistas.

El lector encontrará en ella el pensamiento maduro del jurista, presentado con un lenguaje que siendo ameno hace verdadero culto a la mejor lengua española, precisión técnica envidiable y apoyo en una voluminosa bibliografía, en la que no faltan los más recientes y valiosos aportes de la doctrina internacional, aplicados en la medida de lo técnicamente viable, a la normativa nacional. Así se postulan interpretaciones actualizadas a varias normas, sin perder de vista la coherencia sistemática y procurando en todo caso el delicado equilibrio entre el dogma penal y las garantías constitucionales.

La obra no es inaccesible para los estudiantes de Derecho, pues el argumento coherente, la expresión clara y la oportuna ejemplificación admiten varios niveles de lectura, desde aquel del alumno hasta el del especialista, aunque a todos y en diversa medida, la obra exija una cuidadosa y atenta lectura, la que por cierto justifica plenamente.

Raúl CerviniProfesor Emérito Derecho Penal- UCUDAL 